\title{
"SOMETHING WICKED THIS WAY COMES": APOCALYPTIC OVERTONES AND THE DESCENT INTO ENNUI IN JOHN LOGAN'S TV SERIES PENNY DREADFUL
}

\author{
Dr. Richard Logsdon, Professor Emeritus, College of Southern Nevada
}

\section{Abstract}

While scholars have provided some insight into Penny Dreadful, no one has addressed the relationship of the piece's overall design to the writer's vision. Indeed, Penny Dreadful is offered as a warning of a darker age to come. Accordingly, writer John Logan sets his series in a late Victorian, Gothicized London that serves as a microcosm for a contemporary Western world experiencing a psychological and spiritual disintegration that touches the individual and the larger culture. Logan calls attention to the anxieties generated by this disintegration by incorporating into his series characters from late Victorian Gothic fiction: Frankenstein and his creature, Dracula, the Wolf Man, Dorian Gray, and Dr. Jekyll. The individual and cultural anxieties suggested by these characters' "monstrous" behaviors have their basis not only in their sexual dysfunctions but in their despair over God's absence. This crisis is centered in sexually adventurous Vanessa Ives, whose attempts to return to the Christ Who has rejected her hold the series together. In the series' final episode, just before her death, Vanessa has a vision of Jesus. In response to Vanessa's death, most of the remaining characters are seized by an ennui that has its counterpart in our own culture. The suggestion is that Logan uses Vanessa Ives as a symbolic representation of a dying world view, which, somewhat ironically, provided for her remaining friends a hope that sustained them.

\section{Introduction: Old or New Gothic?}

Since the release of Francis Ford Coppola's Dracula in 1992, Gothic horror films that gave the traditional depiction of the Prince of Vampires have been replaced by tamer, even more domesticated versions of Bram Stoker's monster (Hutchings 4048). Indeed, in the world of cinema and TV, the past two or three decades have seen a movement away from the traditional Gothic horror with its dark and haunted landscapes, terrified females, cruelly oppressive males, monsters, "life-threatening pursuits," gloomy castles, and bleeding statues (Botting 13). Joseph Crawford's The Twilight of the Gothic? provides an excellent study on variations of this trend, focusing finally upon the significance of the recent Twilight series in which vampires and werewolves occupy traditional male and female roles and emphasizing the significant role that the TV series Buffy the Vampire Slayer played in reshaping the character of 
the vampire in Gothic narrative. Crawford finds support from writer Roxanne Longstreet, author of the Rachel Cain series, who affirms that "most editors in traditional publishing that I've spoken to are no longer seeking vampire-themed material" (Qtd. in Crawford 271). Further support comes from Tim Kane, author The Changing Vampire of Film and Television, and from scholar Jessica Groper, who has commented, "[T]here is now a generation that views the vampire characters not as terrifying and evil but as romantic and compassionate" (Qtd. in Crawford 271-272).

From time to time, however, exceptions have emerged.

Among these exceptions, the most notable may be John Logan's recent threeseason series Penny Dreadful (Showtime and Sky TV, 2014-2016), a TV series set in a late nineteenth century Victorian London that serves as a microcosm for our own world, one in which the seeming absence of God has become the context for "monstrous" acts, often rooted in sexual dysfunction, that are fed by and contribute to the larger malaise that seems to accompany the disintegration of a culture once rooted in the now fading Christian paradigm.

The success of this fast-paced series, as it touches upon the anxieties created by the sense that contemporary culture is disintegrating, has much to with Logan's use of dark and foggy streets and his recreation of a thoroughly Gothicized London, one filled with creatures of the night. In line with the traditional vampire-based Gothic, Logan's Penny Dreadful has given the viewer a universe in which Dracula exists as the clear prototype of the devil, the target of whose machinations is the aristocratic, sexually adventurous Vanessa Ives. However, what most sets Logan's piece apart from other recent Gothic works, cinema and TV series included, is a subtly prophetic, even didactic dimension, one that has gone unnoticed. Convinced that his own contemporary world is moving into a new, possibly darker age, Logan sets his penny dreadful in a late Victorian London that has been seized by a dread over the disintegration of their own culture (Connally). In fact, Logan has commented that he sets the action of his TV series in late nineteen century London precisely because the Victorians, like his contemporary audience, dreaded the "Modern Age" to come:

...The Victorian Era was a highly specialized era. And why I chose to set the show then was not because it's a cool visual to bring these characters together, but because there's something about the Victorian Era that reminds me of right now. They were on the cusp of a modern world. The agrarian economy has been replaced by industrial economy. They're looking across the ocean to Germany and America. They were grappling with the very elemental question of what it is to be human, with Darwinism and evolution.... I don't understand any of the new world that's zooming toward us. I think we're on the cusp of the same thing now, and it's frightening and there's dissonance and there's excitement about uncharted waters." (Radish) 
To enable the viewer to grasp the dread that the Victorians felt over moving into a period that they had already acknowledged as "the Modern Age," Logan does two things: he relies upon the bloody sensationalism associated with traditional Gothic horror, and he incorporates into his script a host of familiar Gothic characters that create, for the viewer, a sense of sustained terror. These characters include Frankenstein and his creature, the Wolf Man, Dorian Gray, and Dr. Henry Jekyll. In fact, Logan uses these characters and their monstrous behaviors (rape, murder, unrestrained sexual debauchery, and mass killings) in a script that represents a "codification" of our own world, one in which such anti-social behaviors are a clear indication of spiritual and psychological disorders, often fueled by sexual dysfunction, to which contemporary psychologists apply such labels as sociopathic, psychopathic, schizophrenic, and narcissistic. In short, Logan seems to be pushing the viewers to consider the connection linking these disorders to the larger malaise or contagion occasioned by cultural disintegration of both the late Victorian world and our own present culture.

In this series, this malaise brings an almost paralyzing despair, or ennui, born of the growing conviction that God has vanished or never existed at all. In fact, it is this ennui, a term museum curator Ferdinand Lyle uses in the opening episode of season three to describe Vanessa's own depression, that provides the strongest connection between the climate of Logan's late
Victorian world and the current anxieties awakened by such horrors as the rise of global and domestic terrorism, numerous mass murders committed, unwarranted police shootings of African Americans, "viral outbreaks," natural disasters, global warming, and a return of that dread once associated with a nuclear war waged by the world's super-powers ("The New Cold War"; Brooks).

\section{Why the Penny Dreadful?}

To capture the anxiety and subsequent malaise of the late Victorian age and, by extension, our own troubled age, Logan makes unexpected use of the penny dreadful, a subgenre of Gothic literature. Traditionally, the success of the penny dreadful - or "bloods," as they were called - had nothing to do with literary merit and everything to do this sub-genre's appeal to the basest elements of humanity. The penny dreadful itself, generally known for bloody spectacle and tasteless sensationalism, emerged in mid-nineteenth century England as a phenomenally successful sub-genre of Gothic literature. According to British historian and author Judith Sanders,

The bloods were astonishingly successful, creating a vast new readership. Between 1830 and 1850 there were up to 100 publishers of penny-fiction, as well as the many magazines which now wholeheartedly embraced the genre. At first the bloods copied popular cheap fiction's love of late 18thcentury gothic tales, the more 
sensational the better, 'a world,' said one writer, 'of dormant peerages, of murderous baronets, and ladies of title addicted to the study of toxicology [the study of poison], of gipsies [sic] and brigand-chiefs, men with masks and women with daggers, of stolen children, withered hags, heartless gamesters, nefarious roués, foreign princesses...'

As his penny dreadful moves from bloody scene to bloody scene, Logan gives his viewers a remarkably insightful and unified work, one held together by the story of Vanessa Ives. The series' protagonist, Vanessa is wealthy English woman who fears that God has abandoned her to her struggles against the demonic "Demi Monde" whose master, Dracula, seeks to claim her as the "Queen of Hell" and cast a world that seems to be coming apart at the seams into everlasting darkness. Considered by Logan as the series" "organizing principle," Vanessa must battle an ancient evil that can be traced back to The Egyptian Book of the Dead, Memoirs of the Devil (fictional piece supposedly written in the Middle Ages by a fictional Brother Gregory) and the Bible (Gosling 22). As Logan himself has pointed out, Penny Dreadful "has always been [about] a woman grappling with her faith [within a London society that seems to have been targeted by this ancient evil.]... [A]t the end of the second season Vanessa stepped away from Catholicism, from religion, and so the third season had to be... about her clawing her way back to God" (Patten). Indeed, Vanessa must work her way back to God in a series that reflects "the embodiments and evocations of cultural anxieties" and "project[s] an uncontrollable and overwhelming power [that] threatens not only the loss of sanity [and] honor but the very order" of society (Botting 2, 4). Within this series, this "power" is most immediately related to but not necessarily identifiable with the presence of the demonic, evidence of this "ancient evil," and by the growing apprehensions created by the sense that God has forsaken, or is one the verge of forsaking, the disintegrating Victorian society of the script. Certainly, the pervasive influence of the demonic in Penny Dreadful has its counterpart in the psychological/ spiritual malaise that afflicts not only Logan's late nineteenth century Victorian society but our own contemporary world as well.

\section{III. "We Are All monsters"}

In Penny Dreadful, Logan responds to and even counters this dulling malaise in his own viewers by skillfully weaving together several bloody, action-packed narratives, each centered upon a character whose ongoing battles with his/her darker side reinforces not only Logan's belief that beneath the surface "We are all monsters" (Gosling 15) but the sense of a cultural breaking-apart that manifests itself in the individual characters. Indeed, almost every character in the script has a "monstrous" self-a variation of the "doubling," occasionally found in Gothic works, a word that denotes " $[\mathrm{A}] \mathrm{n}$ essential duality within a single character centered on the polarity of good and evil" ("gothic double") - that he 
or she does little to conceal. But the significance of "doubling" goes beyond the obvious in Penny Dreadful. Throughout this series, each character's struggles with a darker side-generally a very dark version of Jung's "shadow self” (Qtd. in Hoyle)and the emergence of a monstrous personality, which in this series becomes symptomatic of the slow cultural fragmentation of a society in the transition.

The connection between the emergence of the "monstrous" self and the dissolution of the larger culture is reinforced by several subplots, one of which focuses upon the Westerner Ethan Chandler. A cowboy from New Mexico territory, Ethan is driven by his fear and hatred not only of his father but of the distant God Who formed him. Ethan's fears are exacerbated by the violent, bloodthirsty being that exists within him. Specifically, with every full moon, Ethan becomes a murdering and marauding werewolf, who is nonetheless destined to play a significant, divinely-ordained role in the efforts to save Vanessa Ives and thereby prevent the world from being consumed by the Master and his Demi Monde. Introduced as Wild West sharp-shooter, Ethan can be kind man, but he is also a killer whose monstrous self comes into immediate play in the series' first episode, in which he murders and mutilates a baby and its mother and, in a subsequent scene, in which he kills a prostitute that he finds sitting alone on a bench next to a fog-enshrouded street. Ethan's monster surfaces in a later scene in which, seated at Mariner's Inn, he finds himself approached by two detectives that his father has employed to bring him home. Following a hideous and self-willed transformation, Ethan kills one of the two Pinkerton detectives, badly mauls the other, and slaughters anyone else who happens to be inside the establishment. As the London newspaper prints the headline "Jack Is Back," the viewer grasps the connection between Chandler's killings and the Jackthe-Ripper murders, which occurred in 1888, two years before the date ascribed to the fictional Mariner's Inn massacre. In fact, the savage acts of Ethan Chandler establish this character not only as a counterpart to Jack the Ripper but as a symbol for the script's other "monstrous" characters-and, by extension, for the contemporary plague of child predators, mass murderers and serial killers. More importantly, these monsters' own psychological and spiritual conflicts underscore the instability not only of their larger, slowly disintegrating Victorian culture but of our own world as well.

An equally important subplot involves Vanessa's guardian Sir Malcolm Murray, an archeologist who represents England's slowly diminishing colonial empire as well as the flawed white patriarchy upon which this empire depends. In the opening season, hoping to cover for his failure as a father, Sir Malcolm desperately attempts to find and save his daughter Mina from the clutches of the Master, Dracula, and so, in the company of Vanessa Ives and Ethan Chandler he enters a docked ship carrying vampires, engaging them in a bloody confrontation. Later, the viewer learns that on one of his expeditions, Sir Malcolm allowed the death of his son Peter, who apparently failed to live up to his father's code of the heroic, colonizing male and who showed little interest in females. Just as important is the 
fact that Sir Malcolm has committed adultery, an act that Vanessa witnesses and that contributes to Vanessa's own betrayal of her best friend Mina- on the morning of her wedding day, Mina catches Vanessa having sex with her fiancé, cancels the marriage ceremony, and gives herself to another man, the Master himself. Sir Malcolm may even be guilty of incest, a topic discussed later in this essay. To Vanessa, Sir Malcolm is a far cry from the manly, even heroic colonialist; to Vanessa, he is a weak man who is "lustful, vainglorious...obsessive, manipulative, monstrously egotistical" (Gosling 88). A failure as a man raised in the traditionally heroic mode, he has become a monster whose struggles finally culminate in a complete mental breakdown, intended in this series as another symptom of a spiritually and psychologically disintegrating age. Alone in a large room of Evelyn Poole's castle, Sir Malcolm descends into a madness born of his own failures as a male and finds himself confronted by his dead son, his dead daughter, and his dead wife. His insanity, exacerbated by tremendous guilt, is the psychological deterioration of a once-largerthan-life man who has failed to live up to the code of white colonizing male, a stereotype that finds a parallel in our own world in which the slowly disintegrating white patriarchy is marked by failures in leadership and seems on the verge of giving way to a cross-cultural hegemony inclusive of women and people of color.

A third subplot targeting the emergence of the "monstrous" focuses upon Dorian Gray. Fearing death and the biological and psychological deterioration that precedes it,
Dorian has done something that, according to the traditional world view of the late Victorian society, would have been regarded as an act of madness and that may even be intended to reflect our own age's refusal to recognize the existence of absolute evil: before the series even begins, he has bargained away his soul with the devil. The bargain guarantees Dorian a seemingly eternal youth and allows him to embrace a life of unrestrained, even dangerous licentiousness, one that finds temporary fulfillment in sexual liaisons with the demon-possessed Vanessa Ives (Season 1, episode 6) and the American cowboy Ethan Chandler (Season 1, episode 4), in his relationship with the transgender prostitute Angelique (Season 2, episode 2), and in a love affair with Lilly, Frankenstein's third creature (Season 2, episode 6). Beneath a promiscuity that seems to recognize no boundaries lies an even darker side to Dorian. This side, an insidious "shadow self," emerges in his decision to murder his sexual partner, the transgender female Angelique after Angelique discovers a painting that reveals Dorian as a vile, meanspirited old man. Another monster, Dorian kills without remorse or regret. In a later scene, Dorian's "monstrous" side again emerges as he participates in a bloody manage-et-trois with the former prostitute Justine and his current girlfriend Lilly Frankenstein. From a contemporary perspective, Dorian Gray would likely be regarded as a bit of a psychopath, a species of human being that may appear normal but who lacks a sense of right and wrong, is often highly manipulative, has no ability to commiserate or empathize with anyone, and 
may in face prove to be quite dangerous (Viding et. al. R871). Additionally, Dorian's sense of his own "grandiosity," evident in his willingness to be photographed while having sex with the consumptive prostitute Brona Craft, reveals a certain level of narcissism (Ritter et. al. 241). Significantly, Dorian's psychopathic and narcissistic personality, a sure indicator a larger cultural and moral breakdown, finds numerous counterparts in a contemporary, slowly disintegrating society.

One of the most significant of the series' subplots focuses upon young doctor Victor Frankenstein. Frankenstein is torn by the materialistic belief that existence is no more than a series of chemical reactions and his conviction that death is the only avenue to eternal existence in this world. Like Mary Shelly's version of the same character, Logan's Frankenstein is motivated by a fear of death that is rooted in his memory of a mother who died of a terrifying and bloody disease. Quite in line with his counterpart in Mary Shelly's novel, Logan's Victor Frankenstein has spent his professional life attempting to find the chemical and electrical combinations that would have allowed his mother to live and that, simultaneously, will insure a kind of earthly immortality for future generations. Logan's version varies from Shelly's, however, as Victor creates three beings - a "tripling," if you will-whose function is ultimately symbolic. Concerning this, Akilly and $\mathrm{Oz}$ make a valid observation:

[Frankenstein's] second male creature, Proteus, who is introduced to the audience before the first one, seems to represent the erratic, changeable, and helpless nature of man just like the shape-shifting sea god he is named after. The first creature, who eventually adopts the name of the Romantic poet John Clare, becomes the voice of the modern man's frustration, especially when he describes London as a 'steel-hearted city'.... Dr. Frankenstein is an admirer of death and of the poetry of Wordsworth and Keats. His love of death comes from his belief that death is the only means to eternal life. Dr. Frankenstein's deep belief also guides his actions and in a key scene in the show he names his third creature (whose former name, Brona, means 'sadness' in Gaelic) Lily, the flower of resurrection and rebirth. (22-23)

More to the point, in a work in which the writer calls attention to the fact that we're all monsters, the violent actions of John Clare and Lilly Frankenstein reveal a troubled, darker side to the doctor's conflicted, severely split personality. At the core of Victor's personality lies a possible rage over the death of his mother, who begins vomiting blood as her son listens to her reading him a story; over his own inability to help the only woman he has truly loved; and over the existence of a God Who, in the minds of several other characters, seems indifferent to the suffering of humanity. An equally significant factor contributing to Victor's actions is a sexual dysfunction that manifests itself in the young doctor's continually frustrated desire 
for a partner, whether male or female, with whom he can release his pent-up sexual frustrations. (To University of London Senior Lecturer Amit Rai, this breakdown of the larger Victorian culture or society and the violence accompanying it has as one of its causes people afflicted by severe sexual dysfunctions [540].)

Victor's darker side, inclusive of a rage that he does not acknowledge and a sexual dysfunction that he cannot control, is certainly at work when he murders the prostitute Brona Croft, who is dying of consumption at the time (Season 2, episode 1). Seeking a female corpse that he can recreate into an object of his and his creature's desires, Victor smothers Brona with a pillow, gives her new life in his laboratory, and renames her Lilly (Later, he does develop an attraction to Lilly, who only briefly returns his attention.) The murderous act reveals Victor to be, like Dorian, a bit psychopathic, suffering "a personality disorder characterized by lack of empathy and guilt, shallow affect, manipulation of other people and severe, premeditated and violent antisocial behavior" (Viding et. al. R871) Indeed, Logan's Victor Frankenstein, like Shelly's creature, lacks a moral center that would prevent him from acknowledging the evil inherent in his willingness to take another life so that he can proceed with his scientific experiments. Too, Victor's own fragmented personality is symptomatic of the cultural splitting-apart that Logan calls attention to with his Penny Dreadful.

Indeed, Victor Frankenstein's crisis is magnified by two of his three creations, both possessing a monstrous, even violent side. To begin, Lilly's monstrous side is anchored in a sexual dysfunction that took root when, as Brona Croft, she lived as a prostitute and was forced, by her profession, to suffer endless abuse at the hands of her customers. As a new creation, Lilly becomes a woman with an enormous sexual appetite and a desire to dominate, even hurt men, her lover Dorian Gray included. She becomes, in fact, a terrifying embodiment of the often "overpowering femininity," of the "monstrous feminine, that has been long associated with the Gothic mode (Hogle 11, Creed 8, \& Kristeva 140-156). In one scene, for instance, Lilly seduces a man whom she meets in a tavern and strangles him to death while engaging in sexual intercourse (Season 2, episode 7). Later, reacting to a vague memory of the abuse that she suffered as the prostitute Brona Craft, Lilly forms a community of women ostensibly in support of the women's suffrage movement. During one meeting, she encourages each member of a community of former prostitutes to take power over the adult males that have demeaned them, murder one of them, and return with the victim's head (Season 3, episode 6). As another manifestation of a sexual dysfunction that, once again, may reflect upon Victor, Frankenstein's first creation John Clare commits two murders, both fueled by a sexual frustration that he shares with his creator. In one instance, because Victor has not yet provided a mate for him, the creature takes the life of occult specialist Dr. Van Helsing, who has offered to help Victor combat the London underworld's rampant vampirism. In a more extreme case, Clare murders Mr. and Mrs. Putney, a vile and dishonest couple that run a waxworks museum containing waxen 
recreations of some of recent history's bloodiest murders, the White Chapel and Mariner's Inn killings among them). The murder of the Putneys occurs after the creature has allowed himself to be lured into a display cage by Putney's blind daughter, a representation of the female companion that the creature longs for but cannot have (Season 2, episode 9). In short,

Victor's own instability, manifest in the creation and behavior of Lilly Frankenstein and John Clare, reinforces the sense of the ongoing disintegration of the late Victorian culture - and, by extension, of our own civilization.

\section{Vanessa Ives as the Unifying Principle}

Logan firmly anchors these minor narratives to Vanessa Ives' struggles not only with her fear that God has abandoned her but with her own "monstrous yearnings" (Gosling 22). The yearnings, as they fuel her rebellion against God, must be understood within the larger context of her society's transition into the "Modern Age," in which God's absence threatens to become reality. Indeed, Fred Botting has labeled Gothic literature the literature of transgression, "subverting the mores and manners on which good social behavior rested" (4) and Vanessa's transgressions, at least from a traditional Christian perspective, are certainly many: on her road back to Christ, she becomes a witch, a clairvoyant, an adulteress, and a murderer. At some point before the period that she spends with the cut-wife Joan Clayton learning the art of witchcraft, she has a complete breakdown. Suffering from what appears to be a demonically induced psychosis, Vanessa finds herself confined to a mental hospital whose resident physician Dr. Manning notes the psychosexual basis of Vanessa's affliction (Season 1, episode 5). Support for Manning's diagnosis presents itself in the second episode of the first season. Here, during a séance held by sorceress Madame Kali (aka Evelyn Poole), Vanessa reveals herself to be a demon-possessed medium as she goes into grotesque contortions and allows the dead to speak through her and to Sir Malcolm, castigating the man for his adultery, for allowing the death of his son, and for abandoning his daughter Mina to Dracula. This scene may be reflective of the Victorian culture's demonization of those women who shared with Vanessa a sexually adventurous nature that violated longstanding social codes.

Additionally, Vanessa's behavior following the seance confirms the association of her so-called "demonization" with a sexually-active nature that transgresses standards once held by a more stable culture and society, both now slowly disintegrating. Angered by Sir Malcolm's failure as father and husband, Vanessa storms into the backstreets of London where she has a brief sexual liaison with an unidentified male (Season 1, episode 2). In a later scene, she experiences a brief sexual encounter with Dorian Gray. The consequence of this second sexual liaison is a crippling bout of demonic possession from which Ethan Chandler's recitation of the rites of exorcism temporarily frees her. But another factor-sexual abuse and therefore sexual dysfunction - may be at work here. Indeed, the notion of a link connecting 
possible sexual abuse, Vanessa's sexually active nature and her occasional bouts of possession finds confirmation in the later scene in which the Devil seems to enter her surrogate father, Sir Malcolm Murray. Here, Murray is standing next at the foot of the bed containing his ward Vanessa, whose bouts of possession have left her in a catatonic state. After the devil enters him, Sir Malcolm rapes his ward, restores her to somewhat normal functioning, and, in so doing, provides possible confirmation that Vanessa could become the Queen of Hell. On the one hand, this scene may be intended to illustrate a delusional state that has its basis in Vanessa's own beliefs, one that finds a counterpart in delusions that have their roots in contemporary fundamentalist Christianity (Bennett-Smith). On the other hand, the sexual encounter with her surrogate father certainly fuels the suspicion that Malcolm may have sexually abused Vanessa before this point. To Lauren Rocha, Vanessa's psychological and spiritual instability - evident in her catatonic statemay also be a metaphor for an evil that pervades Logan's late nineteenth century society in the form of a rampant "vampirism." Certainly, this "vampirism" finally takes the form of the ennui that afflicts not only several of the other characters in the script but our own culture as well. Indeed, Vanessa's sickness may be "a type of contagion that cannot be quarantined" and that "implicitly foreshadows that [Vanessa's] conflict cannot be resolved because it is not limited to a single body" (31-33). If Rocha is correct, then Vanessa's condition is reflective of a seeming psychic instability experienced by other sexually adventurous women of her own society and possibly of our own contemporary culture.

Vanessa's battles with both her own "monstrous" inclinations and the demonic world that seeks to claim her assume cosmic proportions in the second season and suggest that the factor that most contributes to the disintegration of the series' Victorian world (and, by extension, our own) may be spiritual or supernatural. In this season, museum curator Ferdinand Lyle helps Vanessa, her companions, and the viewers to make sense of Vanessa's role in the battle between God and the devil. To do so, he uses an ancient manuscript titled Memoirs of the Devil, The Egyptian Book of the Dead, archeological artifacts, and hieroglyphic markings beneath the epidermis of a dead vampire to reconstruct the universe in which Vanessa and her companions must wage a seemingly continual war with the powers of darkness. According to Lyle, God long ago cast two rebellious angels (one of whom was certainly Lucifer) from heaven, and while one was confined to Hell, the other was condemned to roam the earth feasting off the blood of humans while maintaining the hope of being united forever with the Queen of Hell, of re-claiming Heaven, and of plunging the universe into eternal darkness. In the universe that Lyle reconstructs, the evil being that pursues Vanessa has an obvious counterpart in Amun-ra (the Egyptian sun god), who intends to claim the goddess Amunette so that she can assume her position as the Queen of Hell (Season 2, episodes $2 \& 4$ ). (The replaying of this cosmic drama takes the form of Dracula's pursuit of Vanessa.) Lyle's detailed 
explanation takes liberties with Egyptian mythology (Pinch 100-101; Budge xcvxcvii), but it does clarify that all the characters, save possibly Dorian Gray and Lilly Frankenstein, must accept that their lives are inextricably bound with Vanessa Ives' struggles with a demonic adversary that seems to threaten the stability of her late Victorian world. Further, it is within this universe, characterized by an ongoing battle between God and the devil, that Vanessa's struggles reach a climax in the final episode of season two. In this episode, she places her crucifix of Jesus into the fire, signaling her attempt to rejection Christ as her Lord and Savior (Season 2, episode 10) and to bring an end to her conflicts with the Demimonde. This action, along with Lyle's reconstruction, lends emphasis to Ethan Chandler's own observation, a paraphrase of Paul's letter to the Ephesians 6:10-13, that the real conflict, the one that fuels the disintegration of the late Victorian world (as well as our own culture?) involves the spiritual powers and principalities in higher places:

Finally, my brethren, be strong in the Lord, and in the power of his might. Put on the whole armour [sic] of God, that ye may be able to stand against the wiles of the devil. For we wrestle not against flesh and blood, but against principalities, against powers, against the rulers of the darkness of this world, against spiritual wickedness in high places....

Like the other characters in this series, Vanessa's struggles with both the demonic realm and her own monstrous inclinations exact a price. In the opening episode of season three, feeling abandoned by both friends and God, Vanessa falls into the already-mentioned debilitating depression, which her friend Ferdinand Lyle identifies as "ennui." Seeking a cure for an ailment that afflicted mid-to-late nineteenth century Europe and that continues to afflict the contemporary world in the form of severe depression (Kuhn 3-9), Vanessa consults the female psychiatrist Dr. Seward, whose counterpart in Bram Stoker's Dracula is a male doctor with the same name. To initiate a cure, Logan's Dr. Seward sends Vanessa through hypnosis, memory therapy, and several visits to the British museum, the result of which seems to remove her fear that Christ has left her but renders her completely vulnerable to the dark powers that have tormented her (Milad 1075-1082). In fact, following her therapist's advice leads Vanessa to London's British Museum, where she meets Dracula, the Master himself masquerading as the biologist Dr. Sweet. Much taken by Sweet, Vanessa allows the Master to seduce her, capitulates to his powers, seems to embrace her predestined roll as the Queen of Hell (Season 3, episodes $7 \& 8$ ), and, barring a miracle, can do little to halt Western civilization's descent into an all-consuming darkness. In short, at this point in the series, the powers of darkness appear to have won, the disintegration of the fictionalized account of late nineteenth Victorian London apparently complete. 


\section{Abandoned by God}

Vanessa's struggles thus play a key role in Logan's design: to create a series that moves from frightening spectacle to frightening spectacle and that simultaneously reflects the fact that everyone possesses a monstrous side, that (as a possible consequence) God seems to have vanished, and that her rapidly disintegrating civilization (and our own, by extension) is moving into a new age that may be born out of acts of violence and characterized by the spiritual malaise once known as ennui.

But the sexual dysfunction, the violence and fears and occasional bouts of madness that the characters of Penny Dreadful experience may have at their basis a dread (and occasional rage) that is rooted in despair and intensified by the sense that God has forsaken Western Civilization. It is a dread verging on despair that Logan seems intent on capturing through several of the series' characters, who are aware of and respond to God's seeming absence. For instance, Brona Croft, on her death bed, responds angrily, even blasphemously to God's apparent indifference to her personal suffering with a "Fuck you, God! (Season 2, episode 1). Evelyn Poole (aka Madame Kali), also wounded by God's seeming abandonment of her, remarks to Ferdinand Lyle, "Despite what you may think, I did not turn from God.... He turned from me.... You tell me, where is $\mathrm{He}$ - in this city of perpetual suffering, in this life...? ... Where is God in the suffering....?" (Season 2, episode 8). Her response to the sense of having been betrayed by God is to worship the Master and, as an obedient servant, bring to him Vanessa Ives, whose identity as the "Queen of Hell" will be finally but only briefly realized. In season three, infuriated by and dreading the role he must assume in the battle for Vanessa's soul, Ethan curses God while reciting The Lord's Prayer over dinner with his father, who stands for Ethan (and possibly the viewer) as a symbol for the stern, often dictatorial God of historic Christianity (Season 3, episode 6).

In surprising contrast to these characters, "God-addicted" Vanessa Ives ("God addicted" is a label that John Clare attaches to her Season 2, episode 2) never seems to lose her belief in and longing for the God/Christ Who has apparently forsaken her. During the first episode of the first season, the viewer finds Vanessa kneeling before her crucifix, desperately praying to Christ, presumably for forgiveness for betraying Mina and for protection from the demon that now torments her. Again, in episode four of the opening season, viewers find Vanessa Ives sitting on a park bench and looking longingly at the Catholic church on the other side of the park. In the final episode of the first season, desperate for deliverance, Vanessa enters the church and asks the priest to exorcise her of the evil spirit, or spirits, that torment her. A man already defeated by darkness, the priest tells Vanessa about his own failed attempt years before to deliver a boy suffering from possession and refuses to perform the ritual, commenting that to have been touched by a demon is like being touched by God (Season 1, episode 8). In the third season, Vanessa's longing for God becomes central. According to Steven Braum, "contemporary Gothic" 
characters often fixate upon their desire for a "lost object" (263), and in Vanessa's case the most significant lost object is God. Logan has intensified this longing for God by incorporating into the series allusions by three British poets, whose verse reveals a desire for a return to a past and more glorious age in place of the seemingly inevitable dissolution of the late Victorian world. One of the poets is the British Romantic William Wordsworth, whose "Intimations of Immortality" is neatly worked into the script. In the series' final scene, Frankenstein's first creature John Clare recites over Vanessa's grave part of "Intimations," a poem in which Wordsworth expresses his longing for a return to the natural world in which he was once able to feel a divine presence:

...But there's a Tree, of many, one,

A single field which I have looked upon,

Both of them speak of something that is gone;

The pansy at my feet

Doth the same tale repeat:

Whither is fled the visionary gleam?

Where is it now, the glory and the dream? (51-57)

The second poet is John Clare, a minor British Romantic whose name Frankenstein's first creature has taken for his own in an effort to claim the humanity that is routinely denied him and whose verses deify the beautiful natural world that, in Victorian England, was finding itself slowly ravaged by the industrial revolution, which did much to produce in London those elements-foggy smog, rampant cholera, the spread of venereal disease, a number of serial killers, many of them women (Luckin 38; Morse 1-12) - that provided a basis for the creation and subsequent reinventions of "Horror London" (Loutitt 3). The third poet is Alfred Lord Tennyson, a towering literary figure of the Victorian Age who dined with the Romantic poets Wordsworth and Coleridge and who represents the transition away from the Romantic period and toward the coming Modern Age. In fact, Logan titles the beginning episode of season three "The Day Tennyson Died." The death of Tennyson signals, in the world of Penny Dreadful (and perhaps in the England of the 1890s), not only the passage of a more glorious age but the loss of the poet's Christian faith, a consequence of the untimely death of his best friend Arthur Hallum and the subject of Tennyson's famous "In Memoriam: To A. H." Indeed, the series' allusions to these three poets create a tension between the desire to return to a more glorious time-typical, by the way, of the Gothic fiction composed during the British Romantic period (Botting 5)and the frightening reality of transitioning into a new age in which the God of old may no longer be present and the beauty of the natural world may disappear. This tension, however, is resolved when Vanessa dies. Once Vanessa dies and experiences a reunion with Christ, one that the viewer never sees, the disintegration of the late Victorian world and the transition into the "Modern Age" become inevitable. 


\section{Of Ennui and Dread}

This longing for the God Who has apparently vanished certainly contributes to the spiritual and emotional sickness-or ennui, according to Ferdinand Lyle-that seizes Vanessa in the first episode of season three. More importantly, the ennui from which Vanessa suffers in the opening episode of season three represents a form of a spiritual malaise that many nineteenth century European intellectuals knew only too well and that historically has taken the shape of agonizing dreariness and depression, emptiness, apathy, and, at its worst, a sense of having been abandoned by a God Who, according to Nietzsche and Heidegger, apparently may never have existed in the first place (Kuhn 1113). Not quite in agreement with the two German philosophers, French Symbolist poet Charles Baudelaire uses his "To the Reader," to emphasize the link joining ennui to the age's embrace of a materialism which prevents the reading public from appreciating art and truth (337-338). In his poem, Baudelaire very clearly associates this ennui with the demonic when he writes, "It is the Devil who holds the reins which make us go! /In repulsive objects we find something charming;/ ...He is Ennui!-His eye filled with an unwished-for tear,/...You know him, reader, this exquisite monster,/ Hypocrite reader,-my likeness,-my brother!"

Author of The Demon of Noontide: Ennui in Western Literature, Reinhold Kuhn provides insights that validate the association of ennui with the demonic in both Baudelaire's famous poem and in Logan's Penny Dreadful and that, in turn, point to the turbulent spiritual condition of contemporary Western Civilization. In fact, Kuhn devotes an entire chapter to discussing the Biblical basis - he cites Psalm 91behind the association of the demonic with the state of mind and spirit that has become known as ennui and that, in the final episode of Penny Dreadful, seems to afflict several of Vanessa's companions. Kuhn goes on to make the point that this debilitating condition has long been associated with Christianity and requires, as a remedy, either an unshakeable faith in God or a level of intense, even addictive activity $(332,378)$ that for years has apparently sustained Vanessa's companions. Kuhn finally links the ennui of the nineteenth and twentieth centuries to the slow disintegration of the Christian church - to "the fermentation of a decomposing Christianity"-and the now decomposing civilization built upon that church (366). He goes on to comment, "[W]e can tentatively define ennui as the state of emptiness that the soul feels when it is deprived of interest in action, life, and the world (be it this world or another), a condition that is the immediate consequence of the encounter with nothingness, and has as an immediate effect a disaffection with reality" (13).

Kuhn's observations, particularly the linking of ennui to an encounter with a demonic "nothing," helps illuminate what happens to Vanessa's friends after she dies in the series' final episode-and it is certainly intended to call attention to a crisis of spirit in our own age. Indeed, it is only after Vanessa's death that her remaining companions begin to wallow in a despair characteristic of an ennui that today, under a 
different name, has brought people to the psychiatrist's office and that reflects the ongoing disintegration and growing powerlessness of the Christian paradigm that once formed the core of Western civilization (Sealy). In fact, these characters' descent into a condition of near emotional and spiritual paralysis and their encounter with a partial version of "the nothing" should not surprise the viewer.

For example, early in the series Victor Frankenstein's comment that life is nothing more than a series of chemical reactions surely reveals the doctor's own spiritual emptiness - and if this is true, then Vanessa's death and Lilly's rejection of him for Dorian Gray merely deepens Victor's malaise. In fact, in the series' final episode, Victor resorts to heroin to cope with his unendurable condition. Again, in the series' final scene, the creature who has taken the name John Clare mourns over the grave of Vanessa Ives, who has likely represented for him the hope that humanity will move away from its tendency to marginalize those perceived as monsters. He, too, has been seized by a hopeless malaise. As a third example, in season two, Sir Malcolm confesses to Ethan an addiction to those exotic travels that give purpose to his own existence. In fact, Sir Malcolm's sense of his own significance is tied to a mountain to which he attaches a family name and to the members of his immediate family, whose willingness to listen to the adventurer's tales reinforce Sir Malcolm's conviction that he has played a significant role in England's colonization of Africa. With the deaths of every one of his family members, no one remains to listen to and validate the man, and so he too descends into a kind of stupor. Dorian Gray is another character who finally to descends into this seemingly demonic malaise. Already bored with existence, Dorian at times seems incapable of truly appreciating beauty on anything but a purely physical dimension and so amuses himself by moving from sexual liaison to sexual liaison. Accordingly, Lilly's final rejection of him pushes Dorian into a state of melancholy and indifference, classic attributes of ennui. Certainly, within the context of the series, Vanessa's death represents the end of a once glorious age and leaves the script's remaining characters, the condition of each reflective of the larger cultural dissolution, with the sense that their lives have amounted to almost nothing.

In his Penny Dreadful, Logan calls attention to a spiritual crisis that, in turn, has exacerbated the monstrous natures and their sexual dysfunctions of the various characters. It's a spiritual crisis for which Vanessa Ives provides a degree of hope as long as she is alive and that Ferdinand Lyle reinforces with his lengthy explanation of an on-going spiritual battle that frames the activities of every other character in the series. But hope flees with Vanessa's death. Following her death, Vanessa's companions are left to face a world from which the demonic has apparently vanished and from which God apparently verges upon absenting Himself. Accordingly, Ethan Chandler seems doomed to remain a beast living under a curse that is played out with every full moon. Very likely, Sir Malcolm will never bury the guilt of his many failures (which do materialize during his brief bout with madness) and will be forced to live out 
his life bearing the burden of his own curse. For Victor Frankenstein, all that remains following Vanessa's death is a sense of tremendous loss and emptiness. For Lilly, there's the ghastly rebirth into something so monstrous that even Dorian fears her. For the creature who named himself John Clare, all that remains following Vanessa's death is a Modern Age characterized by unending dread, conflicts and alienation.

The unconscious dread so clearly associated with ennui (and the concomitant seeming absence of God), particularly in the third series of Logan's series, may find a parallel beyond the script, in the dread and gloom of a contemporary world that seems to have embraced a nightmarish version of a postmodern universe that seems to lack objective meaning and purpose. It's the post-WW II dread, born of anxiety created by a civilization that has lost any sense of direction, that W.H. Auden clearly picks up on in his epic work The Age of Anxiety: A Baroque Eclogue. This dread seems to come very close to the sickness that Holocaust survivor and psychiatrist Viktor Frankl had in mind when he addressed the existential vacuum that formed in the years following World War II and that most notably manifests itself in what he refers to as a "sociogenic neurosis" (94).

Finally, this dread is very likely the condition that Professor of Hebrew and Comparative Literature Richard Friedman has in mind when he makes the point that contemporary Western society "[has] come to feel the disappearance or 'death' of God so consciously and so intensely" (201). He adds that the "awe" that included both fear and wonder and "the feeling of the presence of divinity" have all but vanished in the contemporary world (203) and that "the idea of existence without the deity is a visceral as much as it is an intellectual conclusion. It is frightening" (210). In short, the new world that Vanessa's companions must face is one that provides little spiritual hope for a civilization that has seemingly lost its spiritual center.

\section{Conclusion: So Where Do We Go From Here?}

Logan drew the inspiration for his Penny Dreadful from his reading of several nineteenth century British novels. He began with Mary Shelly's Frankenstein, published anonymously in 1818 , and went on to a series of novels written in an eleven-year period late in the Victorian age. The works include R. L. Stevenson's Dr. Jekyll and Mr. Hyde, published 1886; Oscar Wilde's The Picture of Dorian Gray, published in 1890: Bram Stoker's Dracula and H.G. Wells' The Island of Dr. Moreau, both published in 1896; and Wells' War of the Worlds, published in 1898(Logan "A New Narrative").

According to eighteenth century Irish statesman and philosopher Edmund Burke, the English Gothic fiction from the late eighteenth, and by extension the early and late nineteenth centuries, represented a response to actual fears generated among the English by the French Revolution of 1789. In so doing, they allowed the British readers of the day to come to grips with these terrors (Paulsen). Scholars agree that subsequent works of Gothic fiction have continued to allow readers the impression of 
"imaginatively transcending or overcoming fear and thereby renewing and heightening the sense of self" (Botting 6-10).

In a break with Burkean tradition, however, Logan's Penny Dreadful does not provide viewers with the means of coming to grips with the things that terrify. Nor does Penny Dreadful allow the renewed sense of self often provided by the traditional Gothic (Botting 136). Instead, Logan uses the monstrous acts of his characters as manifestations not only of the horror accompanying later Victorians' transition to the Modern Age but as signs and symbols that the contemporary world is in the process of a similarly frightening transition. It is with this purpose in mind that Logan has given us a narrative in which the Dracula of old is brought back to life. Indeed, Logan's Penny Dreadful reinforces Peter Hutchings' assertion that "Dracula [and the vampire-hordes associated with the traditional Goth] ...will always come back," transformed by writers' and directors' "ongoing attempts to surprise and confound us" (53).

\section{Works Cited}

Akı1lı, Sinan, and Seda Öz. “'No More Let Life Divide...': Victorian Metropolitan Confluence in Penny Dreadful." Critical Survey 28 1: 2016: 15-29. Web. 21 November 2016, Baudelaire, Charles. "To the Reader." Trans. Eli Seigel. Aesthetic Realism Online Library. N.d. Web. 14 Sept. 2016. Orig. printed in Eli Seigel's Hail, American Development. New York: Definition Press, 1968.Web.
Bennett-Smith, Meredith. "Kathleen Taylor, Neuroscientist, Says Religious

Fundamentalism Could Be Treated As A Mental Illness." Huffington Post 31 May 2013:Np. Web. 6 December 2016.

Botting, Fred. Gothic. London and New York: Routledge, 1996. Print.

Brooks, Max. "The Movies That Rose from the Grave." Patterns For College Writing: A Rhetorical Reader and Guide. 13th Edition. Ed. Laurie G. Kirszner and Stephen R. Mandell. New York: Bedford/St. Martin's, 2015. Print. Bruhm, Steven. "The Contemporary Gothic: Why We Need It." The Cambridge Companion to Gothic Fiction. Ed. Jerrold E. Hoggle. Cambridge: Cambridge UP, 2002: 259-276. Print. Budge, E. A. Wallis. The Egyptian Book of the Dead. Trans. E.A.Wallis Budge. New York: Dover Publications, Inc, 1967. Orig. published 1895 by order of the Trustees of the British Museum. Print.

Connally, Kelly. "Penny Dreadful will not return for season 4." Entertainment Weekly 20 June 2016. Web. 24 September 2016.

Crawford, Joseph. The Twilight of the Gothic? Vampire Fiction and the Rise of Paranormal Romance 1991-2012. Cardiff: University of Wales Press, 2014. Print.

Creed, Barbara. The Monstrous Feminine [:]Film, feminism, and psychoanalysis. Reprint of 1994 edition. London and New York: Routledge, 2007. Flanders, Judith. "Penny Dreadfuls." Discovering Literature: Romantics and Victorians. The Exilarchs Foundation. 
British Library Trust. N.d. Web. 26 December 2015.

Frankl, Viktor. Man's Search for Ultimate Meaning. New York: Insight Books Plenium Press, 1997. Print.

Friedman, Richard Elliot. The Hidden Face of God. San Francisco: Harper, 1995. Print.

"Gothic Double." Your Dictionary. Nd. Web. 31 July 2017.

The Holy Bible. King James version. Web. 2 August 2017

Hoyt, Terence. "Carl G. Jung on the Shadow." Practical Philosophy. Web Site. 5 June 2017.

Hurley, Kelly. "British Gothic Fiction: 1885-1930." The Cambridge Companion to Gothic Fiction. Ed. Jerrold E. Hoggle. Cambridge: Cambridge UP, 2002: 189207. Print.

Hutchings, Peter. The Horror Film. Harlow, England: Pearson Education Limited, 2004.

Jacobs, Alan. "Introduction." The Age of Anxiety by W. H. Auden. Ed. Jacobs. Princeton UP, 2012. xi-xlix.

"John Logan Explains 'Penny Dreadful."” The James Bond International Fan Club. 31 December 2013. Web. 21 December 2015.

Kristeva, Julia. Powers of Horror. New York: Columbia UP, 1982. Print.

Kuhl, Danielle C. "Sociopath." Encyclopedia of Social Problems. Ed. Vincent N. Parrillo. Vol. 2. Thousand Oaks, CA: SAGE Publications, 2008. 889. Gale Virtual Reference Library. Web. 1 Aug. 2017.
Kuhn, Reinhold. The Demon of Noontide: Ennui in Western Literature. Princeton: Princeton UP, 1976. Print.

Logan, John. "Penny Dreadful: Literary Roots." Production Blog \#3. Showtime. Video. Web. 17 February 2016.

Luckin, Bill. "“The Heart and Home of Horror': The Great London Fogs of the Late Nineteenth Century." Social History, vol. 28, no. 1, Jan. 2003, p. 31. EBSCOhost, ezproxy.library.csn.edu/login?url=http:// search.ebscohost.com/login.aspx ?direct= true $\& \mathrm{db}=\mathrm{aph} \& \mathrm{AN}=9946900 \&$ site $=$ ehost -live.

Milad, Mohammed R. "Neurological Basis of Failure to Recall Extinction Memory in Posttraumatic Stress Disorder." Biological Psychiatry 15 Dec. 2009 (66: 12): 1075-1082.Web. 23 April 2017.

Morse, Edward A. "Lifting the Fog: Navigating Penalties in the Affordable Care Act." Creighton Law Review, vol. 46, no. 2, Mar. 2013, pp. 207-257. EBSCOhost, ezproxy.library.csn.edu/login?url=http:// search.ebscohost.com/login.aspx?direct= true $\& \mathrm{db}=\mathrm{aph} \& \mathrm{AN}=86880264 \&$ site $=$ eho st-live.

“The New Cold War." 60 Minutes. CBS News. 18 September 2016.

Hoyt, Terence. "Carl G. Jung on the Shadow." Practical Philosophy. Web Site. 5 June 2017.

Paulson, Ronald. "Gothic Fiction and the French Revolution." ELH 48.3 (Fall 1981): 532- 554. Web. 24 December 2015. 
"Penny dreadful." Britannica Academic.

Encyclopedia Britannica, Inc., 2016.

Web. 12 Jul. 2016.

Pinch, Geraldine. Egyptian Mythology: A

Guide to the Gods, Goddesses, and

Traditions of Ancient Egypt. New York:

Oxford University Press, 2002. Print.

Radish, Christina. "John Logan Talks

PENNY DREADFUL, Exploring

Sexuality, and Planning the Series Well

into the Future." Collider 18 January

2014. Web. 24 December 2015.

Rai, Amit S. "Of Monsters, Biopower,

Terrorism and Excess in Genealogies of

Monstrosity." Cultural Studies 18. 4

(July 2004): 538-570. EBSCO.

Academic Search Complete. Web. 1

January 2016.

Ritter, Kathrin, et. al. "Lack of empathy in patients with narcissistic personality disorder." Psychiatry Research 187.1-2 (May 2011): 241-247. Web. 3 August 20177.

Rocha, Lauren. "Angel in the House, Devil in the City: Explorations of Gender in Dracula and Penny Dreadful." Critical Survey 28.1: 2016: 30-39.

Sealey, R. “One Patient's Search For Antidotes To Nihilism In Psychiatry." Psychiatric Rehabilitation 27.3 (2004): 291-294. Web. 23 April 2017.

Viding, Essi, Eamon McCrory, and Ana

Seara Cordosa. "Psychopathy." Current

Biology 24.18 (22 September 2014):

R871-R874. Web. 8 August 2017. 